\title{
Research on the Simulation of Automobile Welding Production Line Based on eM-Plant
}

\author{
Jun $\mathrm{Lu}^{1, \mathrm{a}}$, PengDan Dai ${ }^{2, \mathrm{~b}}$ \\ ${ }^{1}$ College of Logistics Engineering, Wuhan University of Technology, Wuhan, China \\ ${ }^{2}$ College of Logistics Engineering, Wuhan University of Technology, Wuhan, China \\ a317064861@qq.com , bdaipengdan@126.com
}

Keywords : eM-Plant ; automobile welding production line ; simulation

\begin{abstract}
This paper simulates the assembly and processing of automotive body based on eM-Plant platform, considering the characteristics of the layout of integrated automobile processing station and the machining time arrangement of workers. It analyzes the bottleneck problem of the producing process and finds out the ways to enhance efficiency of automobile welding production line.
\end{abstract}

\section{Introduction}

At present, China's automobile welding company generally exist many problem such as Chaotic production layout, unreasonable process schedule, and other aspects. Auto production workshop generally adopt the mode of assembly line work, usually a single work station has carried on the detailed division of labor, so that we can enhance the proficiency of the workers, improve the work efficiency of single work station. But for the whole production line, all of the work station in real time can't completely in synchronism, thus cause the high load station work time is too long, while the low load station work time is too short, leading to the working efficiency of the whole production line is not balanced, low productivity of the enterprise. In this paper, we use eM-Plant to model a automobile welding company's production line.According to the simulation data, we analyzes the bottleneck problem of the producing process and finds out the ways to enhance efficiency of automobile welding production line.It illustrates the application of simulation technology in car welding production line is feasible.

\section{The introduction of EM-Plant}

EM-Plant is a discrete-event simulation tool that helps you to create digital models of logistic systems (such as production), so that you can explore a system's characteristics and optimize its performance. These digital models allow you to run experiments and what-if scenarios without disturbing existing production systems or - when used in the planning process - long before the real production systems are installed. Extensive analysis tools, such as bottleneck analysis, statistics and charts let you evaluate different manufacturing scenarios. The results provide you with the information needed to make fast, reliable, smarter decisions in the early stages of production planning.

Using EM-Plant, you can model and simulate production systems and their processes. In addition, you can optimize material flow, resource utilization and logistics for all levels of plant planning from global production facilities, through local plants, to specific lines.

\section{The analysis of examples}

Automobile welding production line is composed of many working procedures, each working procedure is composed of different working station,each working station needs different number of works and the working time of each station is different too.Table 1 is a processing station list of a 
automobile welding production line, which records each working station processing time and the number of workers required.

Table 1 processing time and the number of workers required of each working station

\begin{tabular}{cccc}
$\begin{array}{c}\text { Station } \\
\text { Number }\end{array}$ & Process Name & $\begin{array}{c}\text { Process } \\
\text { Time }\end{array}$ & $\begin{array}{c}\text { The } \\
\text { number of } \\
\text { workers }\end{array}$ \\
\hline $\mathrm{P}_{1}$ & $\begin{array}{c}\text { Assemble the front cover hinge } \\
\mathrm{P}_{2}\end{array}$ & 45 & 4 \\
$\mathrm{P}_{3}$ & Assemble the Back cover hinge and the front \\
door & 55 & 4 \\
$\mathrm{P}_{4}$ & Adjust the doors & 55 & 6 \\
$\mathrm{P}_{5}$ & Pre-installed the fender & 60 & 4 \\
$\mathrm{P}_{6}$ & Install the fender & 85 & 4 \\
$\mathrm{P}_{7}$ & Adjust the fender & 54 & 4 \\
$\mathrm{P}_{8}$ & Weld the girder end plate & 48 & 2 \\
\hline
\end{tabular}

\section{The modeling and simulation}

Use the combination of a Buffer and a SingleProc to represent a working station then the working station $\mathrm{P}_{1}$ can be represent as figure 1.Use workplace and work pool to represent the number of workers a working station required.Figure 2 shows that working station $\mathrm{P}_{2}$ needs four workers.

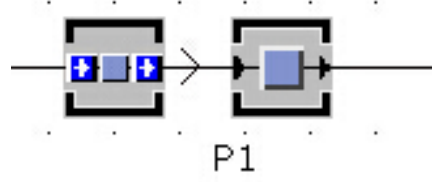

Fig. 1 working station $\mathrm{P}_{1}$

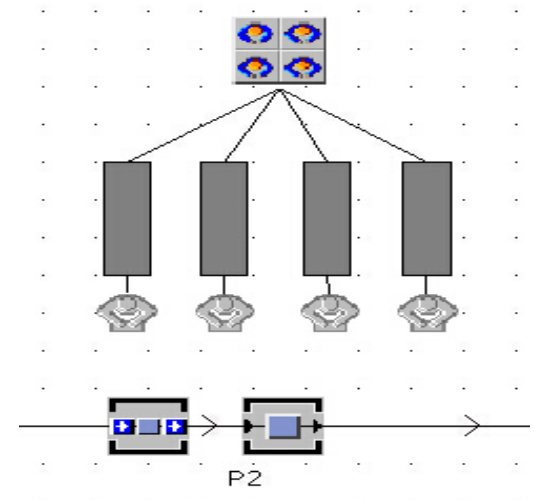

Fig. 2 the workers of working station $\mathrm{P}_{2}$

We set the simulation time 8 hours and run the simulation, we can get the total number of the automobile produced is 328.Utilization of each working station is showed in table 2.

From the table 2 we can see the bottleneck is working station P5 and working station P8 of which the utilization is very high.Because of the high load of these two working station,lead to the high blocked rate of P1,P2,P3,P4 and high waiting rate of P7,P8.So, if we want to enhance the production,we must solve the bottleneck problem.Now,we add 2 workers to working station P5 and working station P8 respectively to reduce the load of these two station.After improvement, we can find the total production enhance to 465 , and the utilization of each working station is showed in table 3 . 
Table 2 The utilization of each working station

\begin{tabular}{cccc}
\hline $\begin{array}{c}\text { Station } \\
\text { Number }\end{array}$ & Waiting/(\%) & Working/(\%) & Blocked/(\%) \\
\hline $\mathrm{P}_{1}$ & 0.27 & 55.16 & 44.57 \\
$\mathrm{P}_{2}$ & 0.59 & 66.44 & 32.97 \\
$\mathrm{P}_{3}$ & 4.32 & 65.48 & 30.21 \\
$\mathrm{P}_{4}$ & 1.49 & 70.38 & 28.13 \\
$\mathrm{P}_{5}$ & 1.84 & 98.16 & 0 \\
$\mathrm{P}_{6}$ & 37.94 & 62.06 & 0 \\
$\mathrm{P}_{7}$ & 45.01 & 54.99 & 0 \\
$\mathrm{P}_{8}$ & 3.14 & 96.86 & 0 \\
\hline
\end{tabular}

Table 3 the utilization of each working station after improvement

\begin{tabular}{cccc}
\hline $\begin{array}{c}\text { Station } \\
\text { Number }\end{array}$ & Waiting/(\%) & Working/(\%) & Blocked/(\%) \\
\hline $\mathrm{P}_{1}$ & 0.63 & 76.30 & 23.07 \\
$\mathrm{P}_{2}$ & 9.59 & 92.28 & 7.13 \\
$\mathrm{P}_{3}$ & 4.77 & 91.32 & 3.91 \\
$\mathrm{P}_{4}$ & 1.41 & 98.59 & 0 \\
$\mathrm{P}_{5}$ & 6.74 & 93.26 & 0 \\
$\mathrm{P}_{6}$ & 12.01 & 87.99 & 0 \\
$\mathrm{P}_{7}$ & 22.09 & 77.91 & 0 \\
$\mathrm{P}_{8}$ & 7.85 & 92.15 & 0
\end{tabular}

From the table 3 we can see the load of each working station become more balanced after improvement.

\section{Conclusion}

In this paper, we use eM-Plant for modeling automobile welding production line,then we analyzes the bottleneck problem of the producing process according the simulation data and finds out the ways to enhance efficiency of automobile welding production line.It illustrates the application of simulation technology in car welding production line is feasible.

\section{References}

[1] Jin Fenghua:The Simulation of a Typical Manufacturing Enterprise Production Logistics System, Jilin University

[2]Peng Wangming, Zhang Xiaochuan:Application of Em-plant in Simulation to Material Flow Operation, Journal of Wuhan University of Technology(Transportation Science \&Engineering)

[3]Yang Kun:The Research on Pipeline Manufacturing Enterprise Production Logistics System Based on Simulation, Chongqing University 
[4]YAO Haifeng, FENG Xunsheng, GUO Ding-jun:Simulation Study on Balancing Technology of Automobile Spare Parts Production Line Using eM -plant,Logistics Technology

[5]Wei Qiyong, Xu Kelin, Jiang Bo : Research on Decision Model of Buffer Area Used by the Manufacturer of Automotive Parts,Diesel Engine 